\title{
Short communication: Can the mammopathogenic Escherichia coli P4 strain have a direct role on the caseinolysis of milk observed during bovine mastitis?
}

\author{
D. Dufour, N. Jameh, A. Dary, ${ }^{1}$ and Y. Le Roux \\ Unité de Recherche Animale et Fonctionalité des Produits Animaux (URAFPA), Nancy-Université, Institut National Recherche Agronomique, \\ Equipe Protéolyse-Biofonctionnalité des Protéines et des Peptides, Boulevard des Aiguillettes, BP239, 54506 Vandoeuvre-lès-Nancy, France
}

\begin{abstract}
During bacterial bovine mastitis, the quality of milk is altered because of caseinolysis. Endogenous potential actors in milk responsible for this caseinolysis have been well studied, unlike the exogenous bacterial ones. The aim of this study was to evaluate the direct role in caseinolysis of a mammopathogenic strain, Escherichia coli P4. Secretion of at least 4 extracellular bacterial caseinolytic enzymes was highlighted by zymography, in 3 different growth media, and at each bacterial growth state, suggesting that their expression was constitutive. Different experimental conditions to evaluate caseinolytic potential did not show any significant caseinolytic activity of $E$. coli $\mathrm{P} 4$ and of the 4 extracellular proteases detected, suggesting that the high caseinolysis observed during E. coli bovine mastitis does result from endogenous milk actors.
\end{abstract}

Key words: mastitis, caseinolysis, Escherichia coli $\mathrm{P} 4$, extracellular bacterial protease

Escherichia coli is recognized as the most frequently encountered bacterial species in bovine mastitis in France (Seegers et al., 1997). Usually responsible for short-lasting clinical mastitis (Blowey and Edmondson, 1995), the mammopathogenic E. coli strains are also commonly associated with recurrent subclinical mastitis (Bradley and Green, 2001). Whether clinical or subclinical E. coli mastitis, significant proteolysis of milk proteins, especially of caseins, is always observed during the disease (Michelutti et al., 1999), leading to important economical and industrial problems for the dairy cattle industry, particularly in the case of subclinical mastitis. Endogenous potential actors responsible for this caseinolysis are the plasminogen-plasmin system and the large panel of proteases produced by the somatic cells recruited during infection, mainly by the polymorphonuclear neutrophils. A study by

Received July 29, 2008.

Accepted November 6, 2008.

${ }^{1}$ Corresponding author: Annie.Dary@scbiol.uhp-nancy.fr
Moussaoui et al. (2004) reported the respective parts of these 2 endogenous factors, but also strongly suggested the existence of exogenous potential actors of caseinolysis; that is, bacterial ones. Indeed, comparing the 2 experimental models currently employed to study E. coli mastitis, LPS and E. coli mastitis models, these authors observed that caseinolysis is more important during an experimental $E$. coli mastitis than during an experimental LPS mastitis, both quantitatively and qualitatively (Moussaoui et al., 2002, 2004). Such an increase in caseinolysis does not seem to result from a more important increase of plasmin activity or from a massive influx of somatic cells in milk during $E$. coli challenge (SCC of $3.98 \times 10^{6}$ and $27 \times 10^{6}$ cells $/ \mathrm{mL}$ were registered during $E$. coli and LPS challenges, respectively, compared with $<10^{5}$ cells $/ \mathrm{mL}$ in healthy milk of a noninflamed udder). Two hypotheses implying an E. coli role in milk proteolysis can account for such results. The first implies an indirect role of $E$. coli consisting of secretion of activators of proteases of somatic cells or secretion of factors inducing maturation of somatic cells and hence of their secreted proteases. The second hypothesis, evaluated in this work, implies a direct role of $E$. coli that would secrete extracellular caseinolytic enzymes.

The bacterial strain chosen for this study was Escherichia coli $\mathrm{P} 4$, isolated from a case of acute bovine mastitis (Bramley, 1976), and used in previous works of our research unit (Moussaoui et al., 2002, 2004). This strain was incubated at $37^{\circ} \mathrm{C}$ in 4 different growth media buffered at $\mathrm{pH} 6.8$ (i.e., milk $\mathrm{pH}$ ) with $0.2 \mathrm{M}$ 3 -( $N$-morpholino)propanesulfonic acid (MOPS) buffer, $\mathrm{pH} 6.8$, to prevent their acidification, which usually occurs during bacterial growth in vitro but not in the udder. Two classical microbial growth media were employed: minimum synthetic medium (MS), containing $7 \mathrm{~g} / \mathrm{L} \mathrm{K}_{2} \mathrm{HPO}_{4}, 2 \mathrm{~g} / \mathrm{L} \mathrm{KH}_{2} \mathrm{PO}_{4}, 0.2 \mathrm{~g} / \mathrm{L} \mathrm{Mg}_{2} \mathrm{SO}_{4}, 1 \mathrm{~g} / \mathrm{L}$ $\left(\mathrm{NH}_{4}\right)_{2} \mathrm{SO}_{4}$, and $4 \mathrm{~g} / \mathrm{L}$ glycerol; and Luria Bertani medium (LB), containing $10 \mathrm{~g} / \mathrm{L}$ bacto-tryptone (Difco, Detroit, MI), $5 \mathrm{~g} / \mathrm{L}$ bacto-yeast extract (Difco), and $10 \mathrm{~g} / \mathrm{L} \mathrm{NaCl}$. Two fresh milk media were also aseptically collected, one from an infused quarter cow $8 \mathrm{~h}$ 

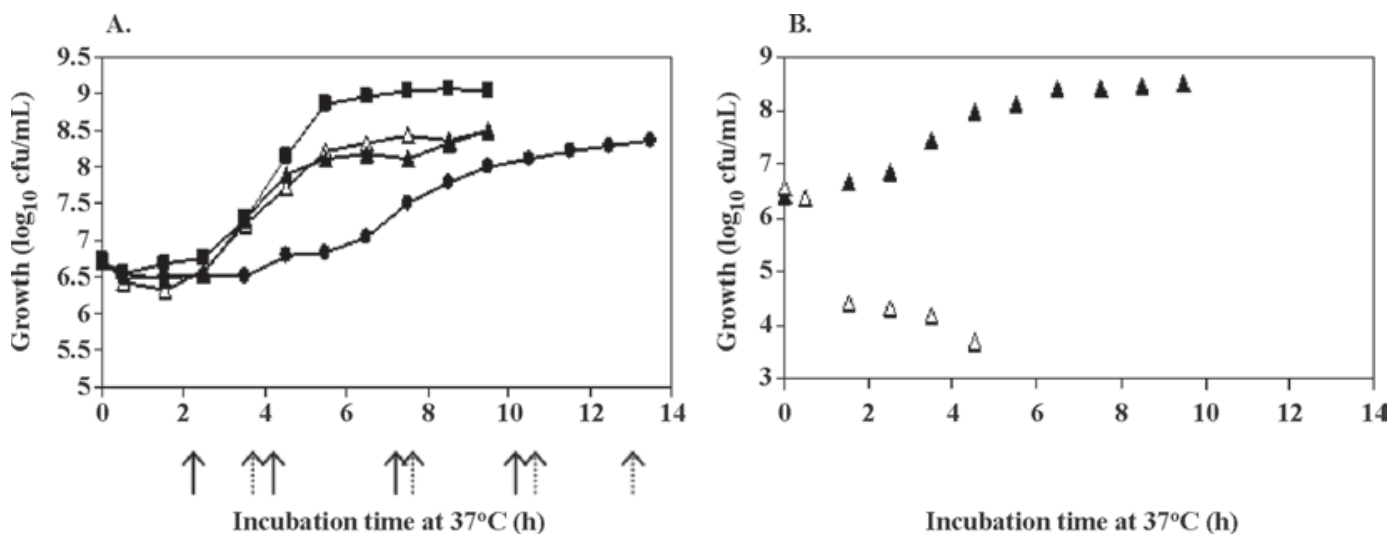

Figure 1. A) Growth curves of Escherichia coli P4 in LPS-fresh milk $(\Delta)$, noninfused fresh milk $(\mathbf{\Delta})$, minimum synthetic medium (MS, •), and Luria Bertani broth (LB, - ). Arrows indicate times at which extracellular bacterial protein samples from milks and LB (solid line), and MS (dotted line) were recovered for zymogram analyses. B) Growth curves of $E$. coli K12 MG1655 in LPS-fresh milk ( $\Delta$ ) and noninfused fresh milk $(\Delta)$.

post-intrammamary infusion of $10 \mu \mathrm{g}$ of E. coli LPS (LPS O26:B6, Sigma Chemical Co., St. Louis, MO), designated LPS-fresh milk (LPSFM), and one from the same cow just before infusion (designated noninfused fresh milk, NIFM). These 2 milks presented $\mathrm{pH}$ values of 6.98 and 6.77 and SCC of $3.56 \times 10^{6}$ and $21 \times$ $10^{3}$ cells $/ \mathrm{mL}$ (determined using a fluoro-opto electronic method), respectively. These $\mathrm{pH}$ and SCC values correspond to typical values of inflamed and healthy milks, respectively. Both milks were skimmed by centrifugation at $4,500 \times g$ for $25 \mathrm{~min}$ at $4^{\circ} \mathrm{C}$, and absence of bacterial contamination was checked by dilution plating on LB solid medium containing bacto agar $(15 \mathrm{~g} / \mathrm{L})$. As shown in Figure 1A, bacterial growth in LB, LPSFM, and NIFM were similar, with a longer exponential growth phase and a greater bacterial count reached in LB. Bacterial growth in MS was slower, probably because this medium was poor in nutrients compared with the other 3 media. As E. coli $\mathrm{P} 4$ belongs to the phylogenetic group $\mathrm{A}$ of the $E$. coli species and as its core genome is very similar to the one of the commensal nonpathogenic E. coli K12 MG1655 strain [D. Dufour, A. Dary, Y. LeRoux, E. Brusseaux (URAFPA), and P. Germon (INRA-Centre de Tours, UR 1282 IASP, Pathogénie Bactérienne, Nouzilly, France); unpublished data], we determined whether the ability of $E$. coli $\mathrm{P} 4$ to grow in LPSFM as well as in NIFM was shared by E. coli K12 MG1655. Growth curves obtained with this strain are presented in Figure 1B. In NIFM, growth of E. coli K12 MG1655 was similar to that of E. coli P4, whereas no growth of the bacterium could be observed in LPSFM. So, it appeared that these strains, which belong to the same phylogenetic group, did not present the same ability to grow in conditions mimicking inflammation (i.e., in antibacterial medium). The E. coli P4 strain, unlike E. coli K12 MG1655, seems to be well adapted to grow in mastitic environmental conditions: its growth curves in LPSFM and NIFM were very similar. This ability of $E$. coli $\mathrm{P} 4$ is not always observed for other mammopathogenic E. coli strains. Indeed, several studies showed that some strains present a longer latent phase in LPSFM than in NIFM, sometimes with an initial decrease in numbers and a lower bacterial count reached in LPSFM compared with in NIFM (Lohuis et al., 1988, 1990).

Extracellular caseinolytic protease secretion by $E$. coli $\mathrm{P} 4$ was examined in the 4 growth media at different times of incubation. Bacterial cultures were stopped by centrifugation at $12,000 \times g$ for $15 \mathrm{~min}$ at $4^{\circ} \mathrm{C}$, after $2,4,7$, and $10 \mathrm{~h}$ of incubation in LPSFM, NIFM, and $\mathrm{LB}$, and after 3.5, 7.5, 10.5, and $13 \mathrm{~h}$ of incubation in MS. These incubation times corresponded to 4 different bacterial growth states: latent state, exponential state, beginning of stationary state, and stationary state (Figure 1A). The supernatants with putative extracellular bacterial proteins were collected, filtered through a $0.45-\mu \mathrm{m}$ filter, dialyzed using a membrane with a 6 - to 8 -kDa molecular mass cutoff (Spectrum, Rancho Dominguez, CA) for $48 \mathrm{~h}$ with $\mathrm{NaN}_{3} 0.01 \%$ (wt/vol), and lyophilized (Hetosicc apparatus, Heto Birkeröd, Denmark). Before any analysis, absence of intracellular components resulting from a total or partial cell lysis was verified by testing for the presence of nucleic acids in the extracellular contents, as described previously (Moe et al., 1994). Putative extracellular bacterial caseinolytic proteases were then searched by a zymography approach using caseins as substrate as described by Haddadi et al. (2006). This SDS-PAGE zymography was performed with $5 \%$ polyacrylamide for the stacking gel in $0.125 M$ Tris buffer, pH 6.8, and with $10 \%$ polyacrylamide for the separating gel in $0.38 M$ Tris buffer, $\mathrm{pH} 8.8$, containing $0.26 \mathrm{mg} / \mathrm{mL}$ 


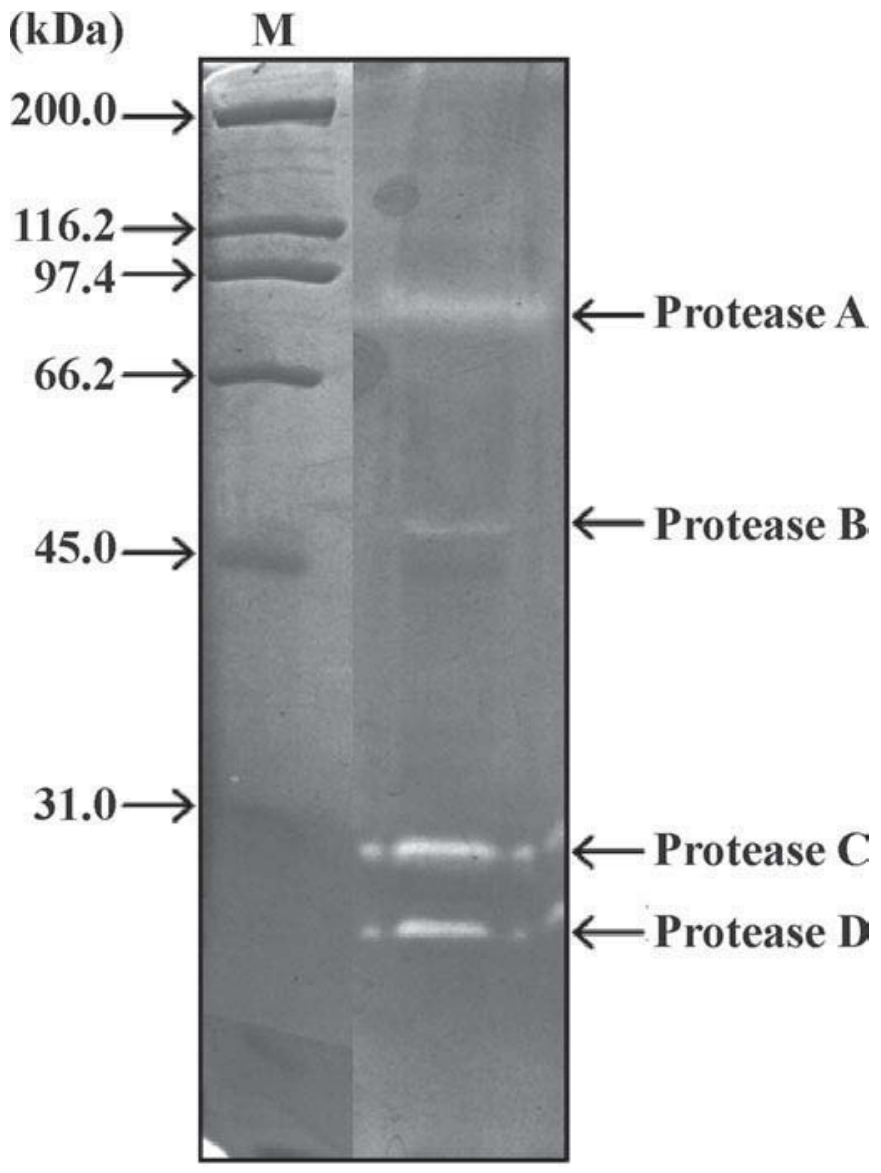

Figure 2. Sodium dodecyl sulfate-PAGE zymogram analysis of Escherichia coli $\mathrm{P} 4$ extracellular content culture from minimum synthetic medium. Clear zones indicate protease activities on Coomassie Blue R250 stained gel. $\mathrm{M}=$ molecular mass standard.

of sodium caseinate salt. About $20 \mu \mathrm{g}$ of extracellular bacterial proteins were loaded in the gel. For NIFM, MS, and LB media and at each growth time tested, 4 casein hydrolysis bands corresponding to at least 4 proteases of apparent molecular weight of 96 (protease A), 54 (protease B), 23 (protease C), and $21 \mathrm{kDa}$ (protease D) were detected specifically in the extracellular samples (Figure 2, data shown only for MS medium), suggesting the bacterial secretion of at least 4 extracellular proteins with caseinolytic activity. Furthermore, the fact that these proteases were detected in different bacterial growth media (NIFM, MS, and LB) and at each growth state (latent, exponential, and stationary) tested, indicated that their expression might be constitutive. Zymograms obtained with extracellular samples of $E$. coli $\mathrm{P} 4$ grown in LPSFM could not be interpreted because of the presence of several proteases of 90, 50, and $25 \mathrm{kDa}$ that were present in the medium before its inoculation, as has been reported previously (Haddadi et al., 2006). Hence, the distinction between endogenous proteases from milk and exogenous proteases from bacteria was not possible.

To visualize the direct caseinolytic activity of the 4 detected extracellular proteases of $E$. coli $\mathrm{P} 4$, extracellular media of 10- and 13-h bacterial cultures in LB and MS, respectively, were incubated for 24 and $48 \mathrm{~h}$ at $37^{\circ} \mathrm{C}$ with total casein solution (prepared in $0.05 \mathrm{M}$ sodium phosphate buffer, $\mathrm{pH} 6.8$, at $1 \mathrm{mg} / \mathrm{mL}$ ). Presence of the 4 proteases in these LB and MS extracellular samples was checked previously by zymography (data not shown). Lipopolysaccharide-fresh milk and NIFM were not used as culture media for this study because of their high initial casein content. The reaction mixtures comprising LB or MS extracellular medium plus caseins were analyzed by SDS-PAGE according to the method of Laemmli and Favre (1973), using 5\% polyacrylamide for the stacking gel in $0.125 M$ Tris buffer, $\mathrm{pH}$ 6.8, and $15 \%$ polyacrylamide for the separating gel in $0.38 \mathrm{M}$ Tris buffer, $\mathrm{pH} 8.8$, and loading about $20 \mu \mathrm{g}$ of proteins per well. Mixtures with equal quantities of extracellular bacterial proteins and of caseins were first incubated and analyzed. No qualitative evolution of caseins was detected on the electrophoretogram, suggesting the absence of hydrolysis (Figure 3A). Mixtures with greater quantities of extracellular bacterial proteins (ratios of 10:1, 20:1, 50:1, and 100:1) were then incubated and analyzed, but hydrolysis was not observed in any of them (data not shown). The same E. coli $\mathrm{P} 4$ extracellular protein samples were incubated for 24 and $48 \mathrm{~h}$ at $37^{\circ} \mathrm{C}$ with each casein fraction; that is, with $\alpha_{\mathrm{S1}^{-}}, \alpha_{\mathrm{S2}^{-}}$, and $\beta-+\kappa$-casein solutions (also prepared in $0.05 \mathrm{M}$ sodium phosphate buffer, $\mathrm{pH} 6.8$, at $1 \mathrm{mg} / \mathrm{mL}$ ) separately, with equal quantities of extracellular bacterial proteins and of caseins, and analyzed as above. The electrophoretogram obtained showed no qualitative evolution in each casein fraction, suggesting again an absence of hydrolysis (Figure 3B, 3C, 3D).

Two types of study were finally undertaken to evaluate the global caseinolytic potential of $E$. coli $\mathrm{P} 4$. In the first study, the global caseinolytic activity of E. coli P4 in milk (i.e., in a growth medium that it encounters when it contaminates the udder and induces inflammation) was analyzed. The LPSFM medium was not used for this study because of its complexity (important endogenous proteolytic activity and advanced hydrolysis of milk proteins). Hence, E. coli $\mathrm{P} 4$ was incubated in NIFM as described previously. The NIFM medium presented a low SCC $\left(21 \times 10^{3}\right.$ cells/mL; i.e., nearly no endogenous proteolytic activity), enabling us to evaluate only the bacterial proteolytic activity. Indeed, with this value of SCC (i.e., $<10^{5}$ cells $/ \mathrm{mL}$ ), milk is considered healthy (Burvenich et al., 2004) and contains mostly macrophages as somatic cells, which present a smaller proteolytic panel than polymorphonuclear neutrophils 
A.

Ctr

EP-MS

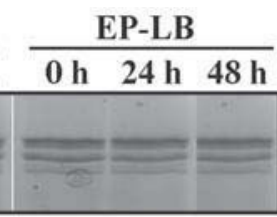

B.

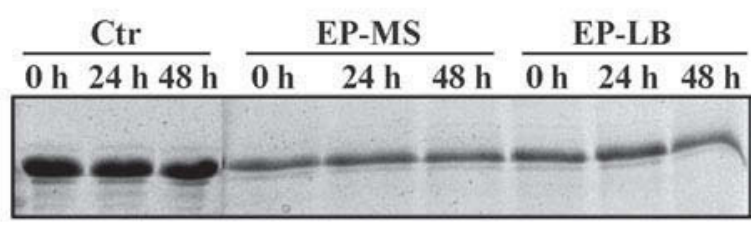

C.

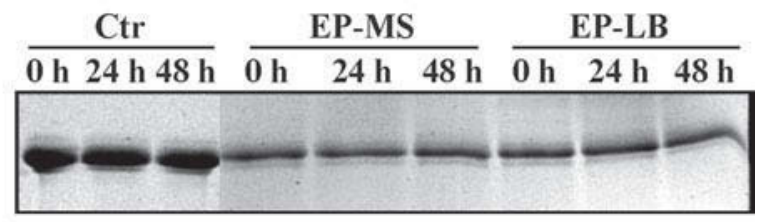

D.

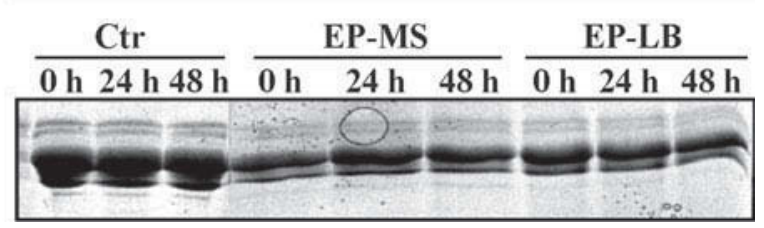

Figure 3. Sodium dodecyl sulfate-PAGE electrophoretograms of total caseins (A), $\alpha_{\mathrm{S} 1}$-casein (B), $\alpha_{\mathrm{S} 2}$-casein (C), and $\beta+\kappa$-caseins (D) alone (Ctr) or mixed with an equal quantity of Escherichia coli P4 extracellular proteins from $13 \mathrm{~h}$ minimum synthetic medium (EP-MS) and $10 \mathrm{~h}$ Luria Bertani (EP-LB) cultures, and incubated for 0, 24, and $48 \mathrm{~h}$ at $37^{\circ} \mathrm{C}$. Gel was stained with Coomassie Blue R250.

(Boutet et al., 2006). At different incubation times, E. coli $\mathrm{P} 4$ growth was determined and found to be similar to that presented in Figure 1A. Evolutions of quantity of caseins and of the type of proteose-peptones were determined at 5 incubation times $(2,4,7,10$, and 24 h), corresponding to 4 bacterial growth states (latent, exponential, beginning of stationary, and 2 stationary states, respectively; Figure 1A, where the point $24 \mathrm{~h}$ is not shown, but is identical to the $10 \mathrm{~h}$ point). Casein content of the bacterial culture was recovered after precipitating caseins by setting the $\mathrm{pH}$ to 4.6 , and the percentage of each casein fraction was determined by fast protein liquid chromatography analysis on a MonoQ HR 5/5 anion-exchange column (Pharmacia, Uppsala, Sweden), according to the procedure of Collin et al. (1991). Proteose-peptone content of bacterial culture was recovered according to the method of Le Roux et al. (1995), and qualitative evolution of proteose-peptones was analyzed by SDS-PAGE according to the method of Laemmli and Favre (1973), using 5\% polyacrylamide for the stacking gel in $0.125 M$ Tris buffer, $\mathrm{pH} 6.8$, and $15 \%$ polyacrylamide for the separating gel in $0.38 \mathrm{M}$ Tris buffer, $\mathrm{pH} 8.8$, and loading about $60 \mu \mathrm{g}$ of proteose-peptones per well. At each of the incubation times tested, the presence of the 4 extracellular caseinolytic enzymes was checked by zymography. A control, cor-

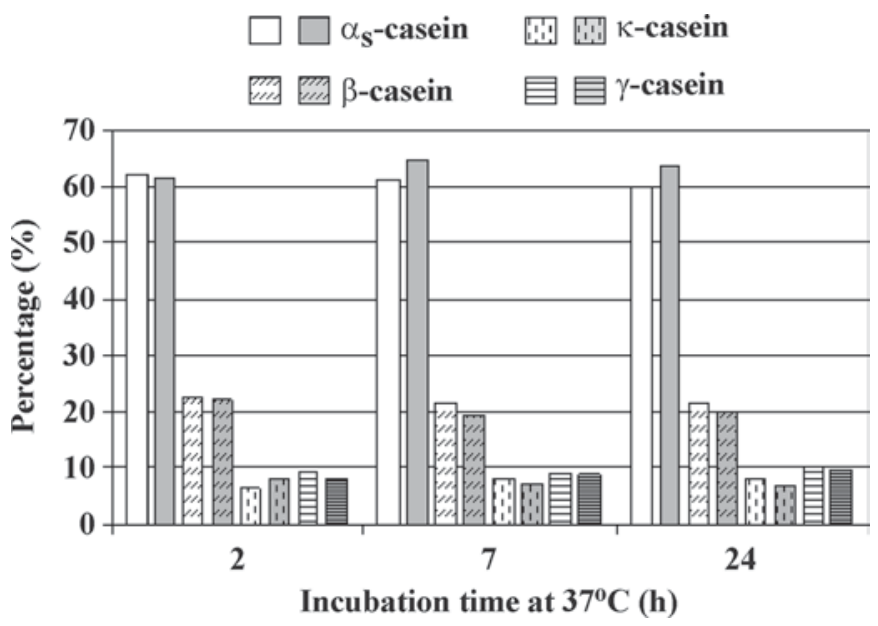

Figure 4. Evolution of each casein fraction, determined by fast protein liquid chromatography analysis, from noninfused fresh milk (NIFM) inoculated with Escherichia coli P4 (bars with white background) or not (bars with gray background), and incubated for 2, 7, and $24 \mathrm{~h}$ at $37^{\circ} \mathrm{C}$

responding to the same healthy milk without bacteria, was also analyzed. No significant variation of the quantity of each casein fraction was observed between the different incubation times and between the inoculated milk and the control (Figure 4). Likewise, no different type of proteose-peptones was detected between the different incubation times and between the 2 milks (Figure 5). Thus, no obvious caseinolytic activity of the bacteria could be detected.

Second, the global caseinolytic activity of E. coli P4 was evaluated by incubating the bacteria in a growth medium with only caseins as nutrient sources. This medium corresponded to MS devoid of glycerol (carbon source) and $\left(\mathrm{NH}_{4}\right)_{2} \mathrm{SO}_{4}$ (nitrogen source), but supplied with a sodium caseinate (Sigma Chemical Co.) solution at concentration similar to milk; that is, $0.15 \%$ (wt/ vol), and initially prepared in a $0.05 \mathrm{M}$ sodium phosphate buffer, $\mathrm{pH}$ 7. In these conditions, the bacteria had to develop, for their growth, proteolytic activity to use caseins as a source of nitrogen and carbon. After more than $200 \mathrm{~h}$ of incubation at $37^{\circ} \mathrm{C}$ in this medium, bacteria were still in a latent growth state, staying at an initial concentration of about $9 \times 10^{6} \mathrm{cfu} / \mathrm{mL}$ (Figure 6). No increase of the bacterial concentration could be observed such as that observed in LPSFM, NIFM, MS, and LB (Figure 1), where, with the same initial inoculum, the bacterial concentrations reached about $10^{9} \mathrm{cfu} / \mathrm{mL}$. The 4 extracellular bacterial caseinolytic proteases were detected by zymography in the culture medium from 5 to $200 \mathrm{~h}$ of incubation at $37^{\circ} \mathrm{C}$. Despite this, no qualitative change in casein content of this medium, analyzed by SDS-PAGE, was observed (Figure 6). Sodium dodecyl sulfate-PAGE was performed according to the method of Laemmli and Favre (1973), 


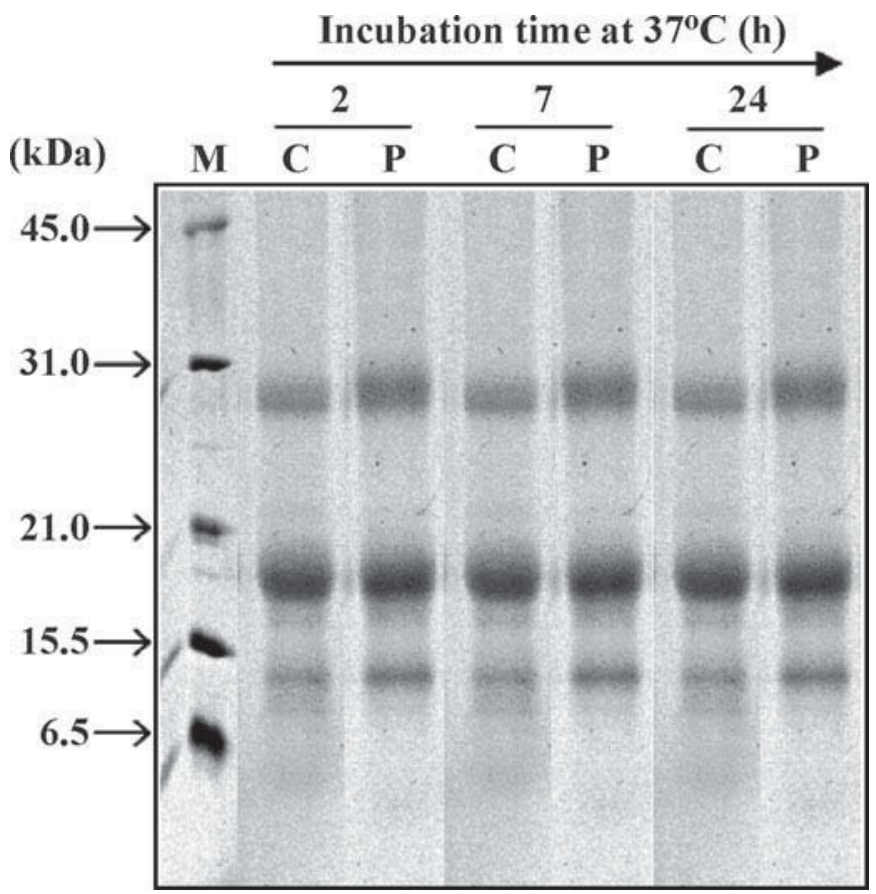

Figure 5. Sodium dodecyl sulfate-PAGE electrophoretogram of proteose-peptone fraction from noninfused fresh milk (NIFM) inoculated with Escherichia coli $\mathrm{P} 4(\mathrm{P})$ or not $(\mathrm{C})$, and incubated for 2, 7, and $24 \mathrm{~h}$ at $37^{\circ} \mathrm{C}$. Gel was stained with Coomassie Blue R250. $\mathrm{M}=$ molecular mass standard.

using $5 \%$ polyacrylamide for the stacking gel in 0.125 $M$ Tris buffer, $\mathrm{pH} 6.8$, and $15 \%$ polyacrylamide for the separating gel in $0.38 M$ Tris buffer, $\mathrm{pH} 8.8$, and loading about $20 \mu \mathrm{g}$ of proteins in the gel. Thus, extracellular proteases detected did not enable the bacteria to use caseins as nutrient sources. These results suggest that caseins do not seem to be the specific substrate of the 4 extracellular enzymes secreted by $E$. coli $\mathrm{P} 4$. The nonspecific caseinolytic activity may be revealed by the zymography approach, which is considered a very sensitive method for protease detection, and by the use of caseins as unique substrate. Caseins are effectively used as a standard substrate (like insulin, gelatin, globin) for protease detection. Many intracellular proteases of $E$. coli have been identified in vitro using caseins as substrate, but they have another function in vivo (Sreedhara Swamy and Goldberg, 1982). It should be interesting to elucidate the exact function of the 4 extracellular enzymes secreted by $E$. coli $\mathrm{P} 4$ because it might result in the discovery of some virulence factors of this mammopathogenic strain. Indeed, several extracellular secreted proteolytic enzymes with virulence properties have been identified in different enteropathogenic and uropathogenic E. coli strains (Dutta et al., 2002).

Although the results obtained in this study showed an effective extracellular secretion by $E$. coli $\mathrm{P} 4$ of 4 enzymes able to degrade caseins by zymography, the

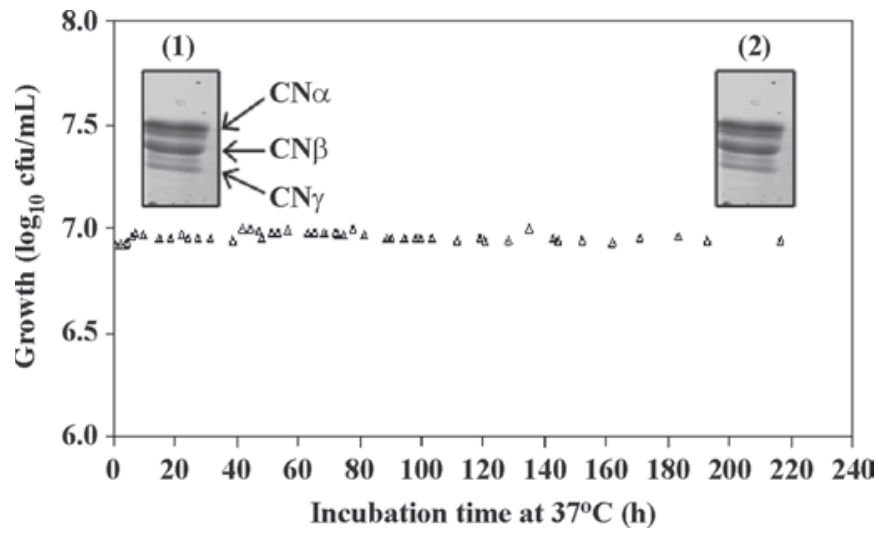

Figure 6. Growth curve of Escherichia coli $\mathrm{P} 4$ in minimum synthetic medium devoid of $\left(\mathrm{NH}_{4}\right)_{2} \mathrm{SO}_{4}$ and glycerol, but supplied with $0.15 \%$ (wt/vol) sodium caseinate (initially prepared in a $0.05 \mathrm{M} \mathrm{pH}$ 7 sodium phosphate buffer) and SDS-PAGE electrophoretogram of caseins in culture medium after 0 (1) and $200 \mathrm{~h}(2)$ of incubation at $37^{\circ} \mathrm{C}$. Gel was stained with Coomassie Blue R250.

different experimental conditions used to evaluate the intensity of caseinolytic potential did not support significant caseinolytic activity of the bacteria or of the 4 enzymes detected. Thus, if these 4 proteases are not expressed at a higher level or if they do not present a greater proteolytic activity on caseins (notably on oxidized caseins) or if E. coli $\mathrm{P} 4$ does not express other proteases during a mastitis event, this work strongly suggests the absence of a direct role of E. coli $\mathrm{P} 4$ in the caseinolysis observed during bovine mastitis. In perspective, the hypothesis of an indirect role of $E$. coli should be studied. Interests should focus on the maturity stage of somatic cells present in milk in the LPS and E. coli mastitis models. Indeed, such stages should be certainly different, and so be associated with different proteolytic panels. If this hypothesis were confirmed, it would be important for the dairy industry to reconsider the technique that implies only detection and count of somatic cells in milk to evaluate its protein degradation. Techniques that involve determination of somatic cell maturation should be considered.

\section{REFERENCES}

Blowey, R. W., and P. W. Edmondson. 1995. Mastitis Control in Dairy Herds. Farming Press, Ipswich, UK.

Boutet, P., F. Bureau, and P. Lekeux. 2006. La mammite bovine: De l'initiation à la résolution. Ann. Med. Vet. 150:1-26.

Bradley, A. J., and M. J. Green. 2001. Adaptation of Escherichia coli to the bovine mammary gland. J. Clin. Microbiol. 39:1845-1849.

Bramley, A. J. 1976. Variations in the susceptibility of lactating and non-lactating bovine udders to infection when infused with Escherichia coli. J. Dairy Res. 43:205-211.

Burvenich, C., E. Monfardini, J. Mehrzad, A. V. Capuco, and M. J. Paape. 2004. Role of neutrophil polymorphonuclear leukocytes during bovine coliform mastitis: Physiology or pathology? Verh. K. Acad. Geneeskd. Belg. 66:97-150. 
Collin, J. C., A. Kokelaar, O. Rollet-Repecaud, and A. DelacroixBuchet. 1991. Dosage des caséines du lait de vache par électrophorèse et par chromatographie liquide rapide d'échange d'ions (FPLC): Comparaison des résultats. Lait 71:339-350.

Dutta, P. R., R. Capello, F. Navarro-Garcia, and J. P. Nataro. 2002. Functional comparison of serine protease autotransporters of enterobacteriaceae. Infect. Immun. 70:7105-7113.

Haddadi, K., C. Prin-Mathieu, F. Moussaoui, G. C. Faure, F. Vangroenweghe, C. Burvenich, and Y. Le Roux. 2006. Polymorphonuclear neutrophils and Escherichia coli proteases involved in proteolysis of casein during experimental E. coli mastitis. Int. Dairy J. 16:639-647.

Laemmli, U. K., and M. Favre. 1973. Maturation of the head of bacteriophage T4. I. DNA packaging events. J. Mol. Biol. 80:575599.

Le Roux, Y., O. Colin, and F. Laurent. 1995. Proteolysis in samples of quarter milk with varying somatic cell counts. 1. Comparison of some indicators of endogenous proteolysis in milk. J. Dairy Sci. 78:1289-1297.

Lohuis, J. A., W. Kremer, Y. H. Schukken, J. A. Smit, J. H. M. Verheijden, A. Brand, and A. S. Van Miert. 1990. Growth of Escherichia coli in milk from endotoxin-induced mastitic quarters and the course of subsequent experimental Escherichia coli mastitis in the cow. J. Dairy Sci. 73:1508-1514.

Lohuis, J. A., W. Van Leeuwen, J. H. Verheijden, J. A. Smit, A. Brand, and A. S. Van Miert. 1988. Growth of Escherichia coli in whole and skim milk from endotoxin-induced mastitic quarters: In vitro effects of deferoxamine, zinc, and iron supplementation. J. Dairy Sci. 71:2772-2781.

Michelutti, I., Y. Le Roux, P. Rainard, B. Poutrel, and F. Laurent. 1999. Sequential changes in milk protein composition after experimental Escherichia coli mastitis. Lait 79:535-549.

Moe, D., C. Garbarsch, and S. Kirkeby. 1994. The protein effect on determination of DNA with Hoechst 33258. J. Biochem. Biophys. Methods 28:263-276.

Moussaoui, F., F. Michelutti, Y. Le Roux, and F. Laurent. 2002 Mechanisms involved in milk endogenous proteolysis induced by a lipopolysaccharide experimental mastitis. J. Dairy Sci. 85:25622570 .

Moussaoui, F., F. Vangroenweghe, K. Haddadi, Y. Le Roux, F. Laurent, L. Duchateau, and C. Burvenich. 2004. Proteolysis in milk during experimental Escherichia coli mastitis. J. Dairy Sci. 87:2923-2931.

Seegers, H., J. L. Menard, and C. Fournichon. 1997. Mammites en élevage bovin laitier: Importance actuelle, épidémiologie et plans de prévention. Renc. Rech. Ruminants 4:233-242.

Sreedhara Swamy, K. H., and A. L. Goldberg. 1982. Subcellular distribution of various proteases in Escherichia coli. J. Bacteriol. 149:1027-1033. 